\title{
Experimental Challenges for Reduced Genomes: The Cell Model Escherichia coli
}

\author{
Masaomi Kurokawa and Bei-Wen Ying * $\mathbb{D}$ \\ Graduate School of Life and Environmental Sciences, University of Tsukuba, 305-8572 Ibaraki, Japan; \\ kurokaw8@gmail.com \\ * Correspondence: ying.beiwen.gf@u.tsukuba.ac.jp; Tel.: +81-(0)29-853-6633
}

Received: 25 November 2019; Accepted: 17 December 2019; Published: 18 December 2019

\begin{abstract}
Genome reduction, as a top-down approach to obtain the minimal genetic information essential for a living organism, has been conducted with bacterial cells for decades. The most popular and well-studied cell models for genome reduction are Escherichia coli strains. As the previous literature intensively introduced the genetic construction and application of the genome-reduced Escherichia coli strains, the present review focuses the design principles and compares the reduced genome collections from the specific viewpoint of growth, which represents a fundamental property of living cells and is an important feature for their biotechnological application. For the extended simplification of the genomic sequences, the approach of experimental evolution and concern for medium optimization are newly proposed. The combination of the current techniques of genomic construction and the newly proposed methodologies could allow us to acquire growing Escherichia coli cells carrying the extensively reduced genome and to address the question of what the minimal genome essential for life is.
\end{abstract}

Keywords: genome reduction; growth rate; experimental evolution; minimal genome; Escherichia coli

\section{Introduction}

Genomic engineering is making remarkable progress. Genome is not only freely edited [1,2], but is also becoming freely synthesizable upon the synthetic design [3]. The bottleneck of genomic engineering is no longer due to technical difficulties but the understanding of the genome itself. The first genomic sequence of Escherichia coli (E. coli), a representative model organism in microbiology, was determined more than 20 years ago [4]. However, the molecular and physiological functions of the whole genomic sequence remained unclear. Although the prediction of the cellular activity and the population dynamics (growth, metabolism, etc.) has been achieved according to the genetic information [5], the simulated consequences were different from the real cell. As the simple E. coli genome is still too complex to be fully explained, efforts have been made to reduce the complexity of E. coli genomes, i.e., removing the redundant genomic regions.

In this review, we comprehensively introduced the genome-reduced E. coli strains constructed so far. The experimental methods used for the genetic construction of the genome-reduced strains have been previously reviewed in detail [6]. Here, we made an effort to review the relationship between the genome reduction and the growth rate of E. coli, because the growth rate was one of the most important global parameters, which quantitatively represents the activity of living cells. Our previous study showed that the accumulation of the genome reduction caused a correlated decrease in the growth rates of E. coli [7]. This finding indicated that the growth rate was a key factor not only in determining the importance of genome size but also in understanding the size-survival relationship. Although a decrease in growth rates of genome-reduced strains has been commonly observed [8], neither the quantitative growth assay nor the specific discussion on the growth of reduced genomes has been 
conducted sufficiently. A thorough overview of the reduced genomes, associated with the growth properties, could provide us with valuable hints of how to construct the fast growing E. coli carrying the reduced genome. Here, we mainly summarized the reduced genomes in the point views of the design principles, growth, and other phenotypic features, if applicable. In addition, we proposed experimental approaches of how to achieve genome reduction without a growth decrease.

\section{Genome Reduction in Synthetic Microbiology}

\subsection{E. coli as a Representative Cell Model}

E. coli has been used as an important and common cell model for genetic and genomic engineering, which has benefited from the organisms' fast growth and ease of genetic manipulation. E. coli has a few nutritional requirements [9] and divide at a very fast rate, exhibiting a 20-min doubling time in nutrient-rich conditions [10]. Since the discovery of restriction enzymes [11], genotypes have become highly operable. E. coli has a relatively high efficiency of transformation due to its ease of plasmid integration [12,13] and phage infectivity [14]. Following the successful transformation of a plasmid vector into E. coli in 1973 [15], intensive studies have been carried out to incorporate foreign genes into E. coli for high levels of gene expression [16-18]. Recently, innovative technologies, such as CRISPER-Cas9, have been put into practical use for genome engineering of E. coli [19], as well as systematic strategies were developed for protein production [20]. Taken together, E. coli is not only a representative cell model but also a powerful cell factory.

As a model organism, E. coli has been studied intensively. The first fully sequenced genome was the wild type E. coli strain K-12 MG1655 [4] in 1997. Although 20 years have passed, both the essential or substantial genetic requirements for $E$. coli are still unclear. Followed by the genome sequencing of another wild type E. coli strain W3110 [21], the molecular functions of approximately $54.1 \%$ of the total genes have been experimentally confirmed [22]. So far, the molecular functions of approximately $63.7 \%$ of the total genes in E. coli have been experimentally confirmed, nevertheless, approximately $28.1 \%$ still remain unpredicted [23]. Even if all the gene functions were identified, it was still difficult to fully explain the dynamics (e.g., growth) of E. coli, because of the complexity of the genetic and metabolic networks in the cell $[24,25]$. Therefore, in order to understand the whole cell as a living system, not only the construction of genetic motifs but also the simplification of genetic composition are required $[26,27]$.

\subsection{Genome Reduction Provides Ideal Cellular Conditions for Synthetic Design}

Remarkable progresses have been made in both the technology and knowledge of synthetic microbiology for industrial applications [28]. Microbiologists have faced the problem that artificial gene circuits and metabolic pathways did not work properly as designed in vitro when they were implemented in vivo [29]. These problems might be caused by the complex genomic background, for example, the heterologous genes in the designed circuit must have been affected by the intrinsic genomic sequence. To solve the problem, a simpler cellular environment of less genetic information was required for predictable control [30]. Reducing the unessential genes and/or metabolic pathways was expected to improve the controllability of the genetic circuits [31]. Although the genome reduction studies were conducted using varied bacterial model organisms (e.g., E. coli [6], Bacillus subtilis (B. subtilis) [32], Corynebacterium glutamicum [33], Pseudomonas putida [34]), B. subtilis and E. coli were most studied [35], owing to the easy manipulation for genetic engineering and the fruitful databases of genomic information [23,36]. Apart from genome reduction, chemical synthesis of genomes, a so called bottom-up approach, was also being used as an approach to build a controllable cell. The most influential bottom-up achievement would be the construction of JCVI-syn1.0, Mycoplasma capricolum living on the synthesized Mycoplasma mycoides genome [37]. The bottom-up approach for bacteria was firstly used for Mycoplasma, which has the smallest genome among cultivatable bacteria. The success in synthetic construction of the reduced genome of E. coli strain MDS42 has recently been reported [38]. 
The approach of genome reduction is a well-established methodology and has been widely performed with E. coli. To date, several genome-reduced E. coli strains have been constructed to acquire controllable cells suitable for bioengineering [39]. The genomic regions that have played a role in adaptation to external disturbance, such as stress response genes [40,41], insertion sequence (IS) elements [42] and transposons [43], seem to be unnecessary for cells cultured in a stable environment in the laboratory. In particular, the ISs and transposons might cause unexpected mutagenesis and be troublesome in genetic engineering by unfavorable genomic mutation [44,45]. Additionally, the retention of these unnecessary genes was thought to increase the cost of DNA replication [46,47], as well as the expression of unnecessary genes can be a burden on microbial growth [48]. Removing these redundant genomic regions might result in cells holding a clean genetic background and simple metabolic pathways. It was supposed to be advantageous for the proper output in vivo that corresponds to the synthetic design in vitro.

\section{Collections of Reduced Genomes}

Genome-reduced E. coli strains have been constructed upon various concepts. Since the details of the genetic construction have been reviewed previously [6], we mainly reviewed the design principles and the growth properties (Figure 1, Table S1).

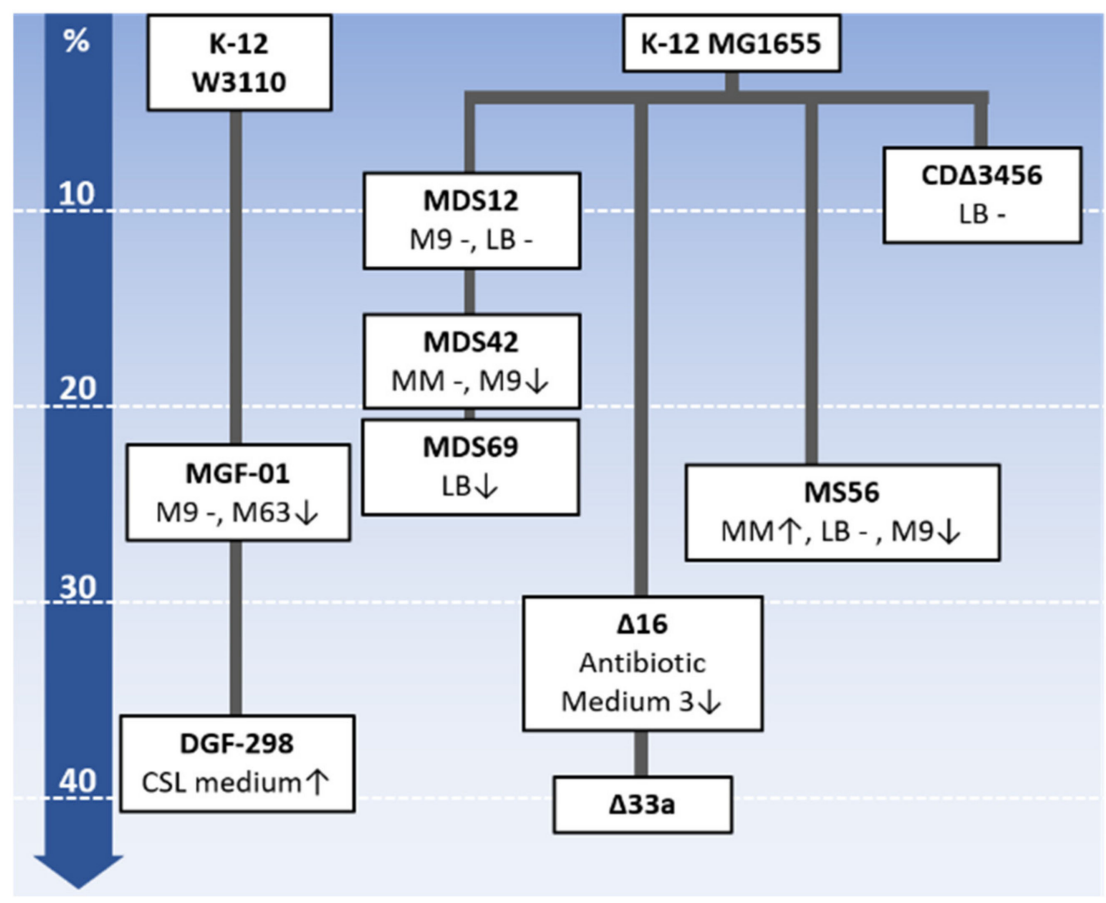

Figure 1. An overview of the genome-reduced E. coli strains. The strains are arranged from top to bottom according to decreasing genome size. The deletions responsible for the percentages in genome size reduction are indicated. The strain name, growth property and medium used are summarized within the boxes. The historical relations among the reduced genomes are connected by bold solid lines. The changes in growth rate are denoted with upward arrows, hyphens and downward arrows, which indicate increased, unchanged and decreased growth rates, respectively. The media used for the growth assay are indicated. The media (LB, MM, M9, M63, CSL medium and Antibiotic Medium 3) used for the growth assay are indicated. The compositions of the media are summarized in Table S2.

\subsection{Minimum Genome Factory (MGF)}

\subsubsection{Design Principles}

MGF was defined as the strain that has only a set of genes necessary for fermentative production and has higher fermentative production capacity than the wild type. MGF-01, which lacked $1.03 \mathrm{Mb}$ 
(22\%) of genomic regions, was constructed based on W3110 [49]. The target regions for deletion were determined as the genomic regions in which 10 or more dispensable genes were continuously located. The dispensable genes were determined by the comparative genomic analysis between E. coli and Buchnera sp., an insect symbiotic bacterium that is divergent from the common ancestor of E. coli [50]. The genes that were only coded in the genome of E. coli were thought to be dispensable. Comparing the two genomes, a total of 95 candidate genomic regions were identified, which led to the draft design of a deduced genome with a size of $2.6 \mathrm{Mb}$. According to the draft design, 53 deletions were combined in one strain via 28 cycles of deletion transfer. MGF-01 series were constructed in consequence. To achieve a reduced genome of higher growth fitness, DGF-298, a $2.98 \mathrm{Mb}$ genome, was subsequently constructed from MGF-01 [51]. The candidates for reduced genomic regions were the functionally unknown genes, harmful genes (for example ISs, prophages, and toxin-antitoxin systems), and the genomic region unique to W3110 revealed by comparative genomic analysis with pathogenic E. coli.

\subsubsection{Growth}

The growth of MGF-01 was similar to that of W3110 in the minimum medium M9 [52,53]. In addition, MGF-01 continued to grow even after W3110 reached the stationary phase, and the saturated cell density was approximately 1.5-fold higher than that of W3110 [53]. However, our previous study showed that the exponential growth rate and the saturated cell density of MGF-01 were lower than that of W3110 in the minimum medium M63 [54], which was evaluated using 96-well microplates [7]. Intriguingly, the decrease in the growth rate was correlated with the reduced length of the genome (Figure 2A, red), and the correlation was more significant under poor nutritional conditions [7]. When MGF-01 was further reduced to $2.98 \mathrm{Mb}$ (DGF-298), both the exponential growth rate and the saturated cell density remained regular [51]. It was assumed that the downregulation of the genes encoding chaperones and proteases might contribute to the growth increase [51]. Additionally, MGF-01 showed 2.4-fold higher L-threonine accumulation than W3110 [53], which was consistent with the initial design hypothesis, that is, the simpler genome resulted in higher productivity.

A

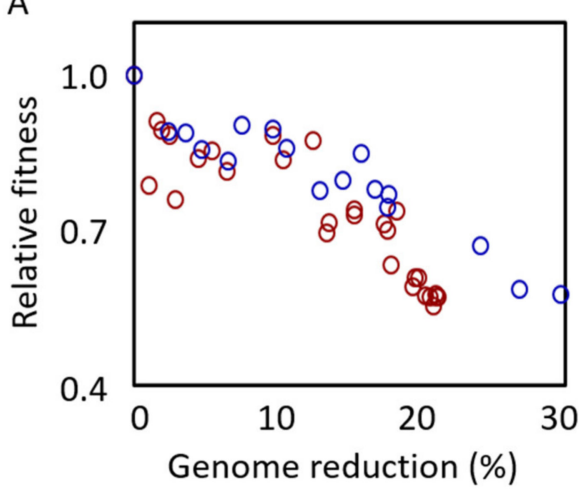

B

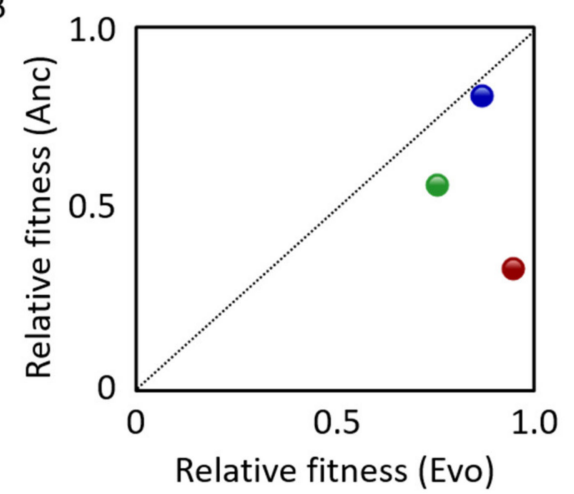

Figure 2. Growth decline and growth recovery of reduced genomes. (A). Correlation between the growth rate and genome reduction. The ratio (\%) of the reduced fragment relative to the wild-type genome is indicated. Relative fitness indicates the ratio of the growth rate of the cells with reduced genomes relative to that of the parent strain cells (wild-type genome). The red and blue circles represent the reduced genomes of the MGF- 01 and $\Delta 16$ derivatives, respectively. The plot was made using the data sets of the previous reports [7,8]. (B). Increased growth fitness attributed to experimental evolution. The relative fitness before (Anc) and after (Evo) experimental evolution are shown. Blue, green and red stand for the genome-reduced strains of MDS42, MGF-01 and MS56, respectively. The growth data was cited from previous studies [55-57]. 


\subsection{Multiple-Deletion Series (MDS)}

\subsubsection{Design Principles}

The purpose of constructing MDS was to create a "tabula rasa" strain practical for introducing foreign genes; the MDS collection was designed to have genetic stability and good metabolic efficiency by removing the ISs from the genome. The first reported strain of the MDS collection was MDS12 [58], which lacked all $12 \mathrm{~K}$-islands, the specific genome region in the K-12 strain, which is equivalent to $8.1 \%$ of the original genome. The additional deletions of IS elements were performed toward MDS12, resulting in the smaller genomes of MDS41. The additional deletions of IS elements were performed toward MDS12, resulting in the smaller genome of MDS41. An endonuclease gene of endA was deleted from MDS41, resulting in the strain of MDS42, and the additional deletion of $45 \mathrm{~kb}$ from MDS42 resulted in MDS43. The genome sizes of MDS41, MDS42 and MDS43 were $14.28 \%, 14.30 \%$ and $15.27 \%$ smaller than the wild type genome, respectively [59]. The target regions for deletion were genomic regions found only in the K-12 strains and not in the strains CFT073, EDL933, RS218, DH10B, O157:H7, and Shigella flexneri 2457T [59]. By genome sequence comparison, 100 genomic regions, corresponding to $20 \%$ of the entire genome and $\sim 900$ genes were proposed to be deleted. Furthermore, 26 additional deletions were performed for MDS43, resulting in the smallest genome MDS69 [60], in which a total length of $939.5 \mathrm{~kb}(20.3 \%)$ of the MG1655 genomic sequence was absent. The candidate regions for deletion were decided by the comparative genomic analysis between MG1655 and its close relatives (E. coli CFT073, EDL933, RS218, DH10B, and Shigella flexneri 2457T). In addition, the genes of unknown functions or coding the surface structures and mobile genetic element were targeted.

\subsubsection{Growth}

No significant differentiation in the growth rates of MDS41 and MG1655 was detected in the minimal medium [59]. In addition, the growth rate of MDS42 was equivalent to that of MG1655 in both the minimum medium MOPS [61] and the rich medium LB [59]. However, another study reported that the growth rate of MDS42 was 20\% lower than that of MG1655 in M9, which was thought to be caused by an increasing proportion of nongrowing cells in the MDS42 population [57]. However, the engineered MDS42 (MDS-205) produced 83\% more L-threonine than the engineered MG1655 [62], which was consistent with the practical metabolic application as in MGF-01 [53]. A comprehensive analysis of a total of 69 MDS strains showed that the genome reduction had no advantage for growth fitness, because the growth rate of MDS69 was 17\% lower than that of MG1655 [60]. The reason why the growth rate lowered was unclear. It was probably attributed to the large fluctuation in transcriptome caused by genome reduction $[63,64]$.

\section{3. $\Delta 16$}

\subsubsection{Design Principles}

$\Delta 16$ was constructed for the purpose of searching for a minimum set of genes sufficient to maintain the cellular functions. It was constructed based on MG1655 and lacked $1.38 \mathrm{Mb}(29.7 \%)$ of the parent genomic sequence [8]. The genes were first classified into "essential", "non-essential" and "unknown", and 163 candidate regions for deletion were determined in accordance [8]. A total of 75 single-deletion mutants and 16 large deletion mutants were constructed. $\Delta 16$ was constructed by integrating the 16 target regions into one strain.

\subsubsection{Growth}

In comparison to MG1655, $\Delta 16$ grew relatively slowly in Antibiotic Medium 3 [8]. The doubling time of MG1655 was $26.2 \mathrm{~min}$, whereas it was delayed to $45.4 \mathrm{~min}$ for $\Delta 16$, which might be related to the changes in the cell shape, as $\Delta 16$ became thick and elongated [8]. No decline in growth was observed in the strains with a single deletion region; nevertheless, the combination of multiple deletion 
regions caused the growth to decrease. Intriguingly, the changes in growth seemed to be correlated with the genome reduction (Figure 2A, blue), which was similar to the result found in the MGF series. These findings indicated that the correlation between genome reduction and growth fitness was a general trend.

\subsection{MS56}

\subsubsection{Design Principles}

MS56 was also constructed based on MG1655 and lacked 23\% of the original genomic regions [65]. This strain was constructed for the purpose of acquiring a highly stable cellular host capable of producing recombinant protein more efficiently. The targeted deletion regions were ISs, K-islands, flagellar genes, ciliated genes, and lipopolysaccharide genes, which were identified according to the $E$. coli data bank.

\subsubsection{Growth}

The growth rate of MS56 was equivalent to that of the wild-type strain in LB [65]. However, the growth of MS56 in the minimal medium presented conflicting results, that is, it was either 1.6-fold faster [65] or significantly slower [55] than that of the wild-type strain. It suggested that the deleted genes might play a role in the nutritional requirements and may be sensitive to slight differences in culture conditions including media compositions.

\section{5. $C D \Delta 3456$}

\subsubsection{Design Principles}

CD $\Delta 3456$ was another MG1655-derived genome-reduced strain [66], which lacked $313.1 \mathrm{~kb}$ of the genomic sequence. This strain was also constructed for determining the minimum set of genes, as did for $\Delta 16$. The Tn5-targeted cre/loxP excision system was used for the construction. Tn5 transposons carrying loxP sequences were randomly placed in the E. coli chromosome, and the region between the two loxPs was deleted by Cre recombination. Six strains with a single deletion region were constructed, and CD $\Delta 3456$ was constructed by deleting four out of the six regions.

\subsubsection{Growth}

There is little information concerning the growth of CD $\Delta 3456$. The only study on it reported that the strain showed a growth rate equivalent to that of the wild-type strain when cultured in LB [66].

\section{Aims and Additional Characteristics of Genome-Reduced Strains}

Differentiation in the phenotypic properties of the reduced genomes somehow resulted from the different design principles and purposes. The genome-reduced E. coli strains of MGF-01, MDS69 and MS56 were constructed for the purpose of achieving simple and highly controllable cells without nonessential genomic regions, and the strains of $\Delta 16$ and $C D \Delta 3456$ were constructed to determine the minimum components essential for maintaining cellular activities. Whether and/or how such differentiation affected the other characteristics is discussed as follows.

\subsection{Genome Stability}

In addition to the growth of the cell population, the stability of the genome was another important factor for the genome-reduced E. coli strains to be used for the aim of metabolite production. It was reported that the mutations caused unexpected disadvantages and reduced substance productivity $[44,45]$. Since the ISs were removed from MDS, the stability of the reduced genome of MDS was supposed to be improved. To verify this assumption, the genome-reduced strain MDS41 and the wild-type strain MG1655 were cultured in the minimum medium containing salicylic 
acid as the only carbon source [59]. To metabolize salicin, the $b g l$ operon was required to be activated. The activation of $b g l$ operon can be achieved by the insertion of ISs into the promoter region [67]. The results showed that the activation rate in MDS41 was only $8 \%$ of that in MG1655, indicating that the IS-related mutation rate was significantly decreased due to genome reduction [59]. Similarly, MS56 showed higher stability for the production of the recombinant proteins than that of MG1655 [65], owing to the disappearance of ISs. The improved stability was considered as advantageous for industrial production, although the capacity of the foreign genes (plasmids) for production might be reduced [68].

The non IS-related mutation rate was equivalent in both strains [59]. On the other hand, the chemostat culture of MDS42 and MG1655 in the minimal medium M9 accumulated an equivalent number of mutations [69]. In addition, the mutation rate of MGF-01 was increased, which was triggered by genome reduction [56]. Thus, genome reduction did not always lead to improved stability. From the view point of industrial production, the improved stability of the genome was advantageous in offering a stable cellular environment; however, the deleted sequences, such as ISs, were thought to be essential for environmental adaptation, e.g., the new insertion of an IS element in MDS42 improved its fitness [70].

\subsection{Genome Minimization}

Genome minimization was discussed for decades, and it was estimated that the minimum gene set contained at least 256 genes, which was determined by the comparative genomic analysis of Mycoplasma genitalium and Haemophilus influenzae in 1996 [71]. However, the essential genes, which were commonly defined as the genes whose single deletion was lethal, were highly variable even within the same species; comparative genomic analysis was insufficient to address this question [72]. Intensive experimental challenges were performed, such as the systematic construction of the single-gene knockout E. coli strains, the Keio collection [73]. The single-gene knockout experiment identified 300 essential genes, however, the deletion of multiple non-essential genes could be lethal [74]. It indicated that the minimal gene set still requires further investigation [75]. The so-called top-down and bottom-up approaches were recently proposed to explore the minimal gene set essential for sustainable life [76]. The top-down approach was to remove the nonessential genome regions of the living cells, that is, genome reduction, which was commonly used in the bacteria of E. coli and B. subtilis [35]. For instance, the largest deletion of genomic sequence in $E$. coli produced the strain $\Delta 33 \mathrm{a}$, in which $38.9 \%$ of the genomic region was deleted from the wild type strain MG1655 [77]. A representative study of genome minimization using the bottom-up approach was the construction of JCVI-syn3.0, which was a Mycoplasma capricolum cell carrying a synthetic genome smaller than any mycoplasma genomes [3]. The recently reported chemical synthesis of the entire genome of E. coli MDS42 using 61 codons was a remarkable achievement of the bottom-up approach for the artificial cells [38]. Accordingly, the expectation of being able to construct the minimal genome artificially from scratch was realistic. However, even if the genome could be fully synthesized, the design principles remained unknown. The top-down approach was thought to be effective, as the trajectory from the wild-type to the minimum genome was supposed to be traceable; in addition, the connection between genome reduction and cellular phenotype could be investigated. The genomic sequence essential for a sustainable life remains to be addressed by genome reduction. Recently, the in silico design of genome reduction according to the metabolic models became applicable [78], which allowed the genome reduction to be more practical and controllable.

\section{Proposals for Further Challenges}

\subsection{Concerns for the Environmental Factors}

Genome reduction without a growth decrease is a key point for both the minimal genome and applications in synthetic microbiology, because the growth rate affected the cell's physiological state, consequently contributing to metabolite productivity [79]. In addition to the genomic sequence itself, the external environment, e.g., media conditions, requires attention. MGF-01 was reported to have an 
equivalent growth rate to W3110 when cultured in M9 [53], but another study reported that MGF-01 grew slower than W3110 when cultured in the minimal medium M63 [7]. The growth rate of MGF-01 declined with increasing genome reduction, and the growth rate decrease was more significant under malnutrition conditions [7]. MS56 presented a declining growth rate in the minimal medium M9 but maintained a growth rate equivalent to that of MG1655 in the rich medium LB [55]. The results strongly indicated that the growth decline caused by the genome reduction could be compensated for by the external conditions. In wild nature, the genomes of the symbiotic bacteria were largely reduced during evolution, which was probably owing to nutritional supplementation from hosts $[47,80]$. Thus, it is more reasonable to rely on external nutrition than to keep the genes that synthesize nutrition on their own when external nutrition can be obtained. In addition to growth rate, genome stability might be affected by medium composition. Although the clean genome MDS42 was constructed for stability, it showed mutation rates similar to that of the wild-type strain under the minimum medium [69]. It was assumed that the reduced genome might be more sensitive to medium composition. The malnutrition induced the stress-induced mutagenesis, which reduced genome stability.

\subsection{Approaches for Experimental Evolution}

It was assumed that modern E. coli has the optimal genome due to its 3.7 billion years of evolution since the origin of the microorganism [81]. Genome reduction could be stressful for E. coli, so that the growth rate would be decreased. Experimental evolution was an efficient approach to raise the growth fitness of bacterial cells, because it simulated evolution by reproducing the conditions in which the better-adapted mutated cells were selected as the generation that continued. Experimental evolution has been widely employed in the studies on the mechanisms of adaptive evolution. In addition to long-term evolution [82], the adaptive evolution to toxic environments [83-85], various temperatures [86-88] and $\mathrm{pH}$ conditions [89], has been reported. These studies commonly showed the gradually increased growth rates, which might be caused by beneficial mutations [90-92]. This approach was practical for the reduced genomes as well (Figure 2B). During the serial transfer, MGF-01 recovered its growth by approximately 400 generations [56], and MS56 matched the growth rate of MG1655 after the experimental evolution of $~ 800$ generations [55]. Chemostat culture of MDS42 and MG1655 for 21 days led to a significant increase in MDS42 growth but not MG1655 growth [57]. These results clearly demonstrated that the experimental evolution was efficient in increasing the growth of reduced genomes for further reduction. The reasons for the increased growth rates caused by the experimental evolution are still unclear; the increase in translation efficiency [55] or the increase in fast-growing cells in the population [57] have been proposed as explanations. In addition, the consequence of experimental evolution has often been linked to the homeostasis of biological systems. The metabolic system, which was disrupted by gene knockout, was reported to be re-optimized by the experimental evolution [93]. Besides, the gene expression disturbed by the changes in nutrient sources or temperature has tended to be close to the original expression pattern [94]. These findings suggest that experimental evolution has helped living cells carrying either a complete or a reduced genome to reach a steady physiological state and/or proper growth fitness. The genome reduction associated with experimental evolution may allow us to achieve a more efficient cell factory as well as the minimal genome.

Supplementary Materials: Supplementary materials can be found at http:/www.mdpi.com/2076-2607/8/1/3/s1.

Author Contributions: M.K. and B.-W.Y. conceive the research and write the paper. All authors have read and agreed to the published version of the manuscript.

Funding: This work was partially supported by the JSPS KAKENHI, Grant-in-Aid for Scientific Research (B), grant number $19 \mathrm{H} 03215$ (to B.-W.Y.).

Conflicts of Interest: The authors declare no conflict of interest. 


\section{References}

1. Ostrov, N.; Landon, M.; Guell, M.; Kuznetsov, G.; Teramoto, J.; Cervantes, N.; Zhou, M.; Singh, K.; Napolitano, M.G.; Moosburner, M.; et al. Design, synthesis, and testing toward a 57-codon genome. Science 2016, 353, 819-822. [CrossRef] [PubMed]

2. Zhao, D.; Yuan, S.; Xiong, B.; Sun, H.; Ye, L.; Li, J.; Zhang, X.; Bi, C. Development of a fast and easy method for Escherichia coli genome editing with CRISPR/Cas9. Microb. Cell Fact. 2016, 15, 1-9. [CrossRef] [PubMed]

3. Hutchison, C.A.; Chuang, R.Y.; Noskov, V.N.; Assad-Garcia, N.; Deerinck, T.J.; Ellisman, M.H.; Gill, J.; Kannan, K.; Karas, B.J.; Ma, L.; et al. Design and synthesis of a minimal bacterial genome. Science 2016, 351. [CrossRef] [PubMed]

4. Blattner, F.R.; Iii, G.P.; Bloch, C.A.; Perna, N.T.; Burland, V.; Riley, M.; Collado-vides, J.; Glasner, J.D.; Rode, C.K.; Mayhew, G.F.; et al. The Complete Genome Sequence of Escherichia coli K-12. Science 1997, 277, 1453-1462. [CrossRef] [PubMed]

5. King, Z.A.; Lloyd, C.J.; Feist, A.M.; Palsson, B.O. Next-generation genome-scale models for metabolic engineering. Curr. Opin. Biotechnol. 2015, 35, 23-29. [CrossRef] [PubMed]

6. Choe, D.; Cho, S.; Kim, S.C.; Cho, B.K. Minimal genome: Worthwhile or worthless efforts toward being smaller? Biotechnol. J. 2016, 11, 199-211. [CrossRef]

7. Kurokawa, M.; Seno, S.; Matsuda, H. Correlation between genome reduction and bacterial growth. DNA Res. 2016, 23, 517-525. [CrossRef]

8. Hashimoto, M.; Ichimura, T.; Mizoguchi, H.; Tanaka, K.; Fujimitsu, K.; Keyamura, K.; Ote, T.; Yamakawa, T.; Yamazaki, Y.; Mori, H.; et al. Cell size and nucleoid organization of engineered Escherichia coli cells with a reduced genome. Mol. Microbiol. 2005, 55, 137-149. [CrossRef]

9. Marr, A.G. Growth rate of Escherichia coli. Microbiol. Rev. 1991, 55, 316-333.

10. Sezonov, G.; Joseleau-Petit, D.; D'Ari, R. Escherichia coli physiology in Luria-Bertani broth. J. Bacteriol. 2007, 189, 8746-8749. [CrossRef]

11. Linn, B.Y.S.; Arber, W. Host specificity of DNA produced by Escherichia coli, X. In vitro restriction of phage fd replicative form. Proc. Natl. Acad. Sci. USA 1968, 59, 1300-1306. [CrossRef] [PubMed]

12. Dower, W.J.; Miller, J.F.; Ragsdale, C.W.; Group, M.B.; Laboratories, B.; Medical, S. High efficiency transformation of E.coli by high voltage electroporation. Nucleic Acids Res. 1988, 16, 6127-6146. [CrossRef] [PubMed]

13. Hanahan, D.; Harbor, C.S. Studies on transformation of Escherichia coli with plasmids. J. Mol. Biol. 1983, 166, 557-580. [CrossRef]

14. Morse, M.L.; Esther, M.L.; Joshua, L. Transduction in Escherichia Coli K-12. Genetics 1956, 41, $142-156$. [PubMed]

15. Cohen, S.N.; Chang, A.C.Y.; Boyer, H.W.; Helling, R.B. Construction of Biologically Functional Bacterial Plasmids in Vitro. Proc. Natl. Acad. Sci. USA 1973, 70, 3240-3244. [CrossRef]

16. Itakura, K.; Hirose, T.; Crea, R.; Riggs, A.D.; Heyneker, H.L.; Bolivar, F.; Boyer, H.W. Expression in Escherichia coli of a Chemically Synthesized Gene for the Hormone Somatostatin. Science 1977, 198, 1056-1063. [CrossRef]

17. Collins, D. Expression of Naphthalene Oxidation Genes in Escherichia coli Results in the Biosynthesis of Indigo. Science 1983, 222, 167-170.

18. Rosano, G.L.; Ceccarelli, E.A. Recombinant protein expression in Escherichia coli: Advances and challenges. Front. Microbiol. 2014, 5, 1-17. [CrossRef]

19. Jiang, Y.; Chen, B.; Duan, C.; Sun, B.; Yang, J.; Yang, S. Multigene editing in the Escherichia coli genome via the CRISPR-Cas9 system. Appl. Environ. Microbiol. 2015, 81, 2506-2514. [CrossRef]

20. Rosano, G.L.; Morales, E.S.; Ceccarelli, E.A. New tools for recombinant protein production in Escherichia coli: A 5-year update. Protein Sci. 2019, 28, 1412-1422. [CrossRef]

21. Hayashi, K.; Morooka, N.; Yamamoto, Y.; Fujita, K.; Isono, K.; Choi, S.; Ohtsubo, E.; Baba, T.; Wanner, B.L.; Mori, H.; et al. Highly accurate genome sequences of Escherichia coli K-12 strains MG1655 and W3110. Mol. Syst. Biol. 2006, 2, 1. [CrossRef] [PubMed]

22. Riley, M.; Abe, T.; Arnaud, M.B.; Berlyn, M.K.B.; Blattner, F.R.; Chaudhuri, R.R.; Glasner, J.D.; Horiuchi, T.; Keseler, I.M.; Kosuge, T.; et al. Escherichia coli K-12: A cooperatively developed annotation snapshot-2005. Nucleic Acids Res. 2006, 34, 1-9. [CrossRef] [PubMed]

23. Kothari, A.; Krummenacker, M.; Latendresse, M.; Peter, E. The EcoCyc Database. EcoSal. Plus 2019, 8, 1-34. 
24. De Smet, R.; Marchal, K. Advantages and limitations of current network inference methods. Nat. Rev. Microbiol. 2010, 8, 717-729. [CrossRef]

25. Shen-Orr, S.S.; Milo, R.; Mangan, S.; Alon, U. Network motifs in the transcriptional regulation network of Escherichia coli. Nat. Genet. 2002, 31, 64-68. [CrossRef]

26. Cameron, D.E.; Bashor, C.J.; Collins, J.J. A brief history of synthetic biology. Nat. Rev. Microbiol. 2014, 12, 381-390. [CrossRef]

27. Smanski, M.J.; Zhou, H.; Claesen, J.; Shen, B.; Fischbach, M.A. Synthetic biology to access and expand nature's chemical diversity. Nat. Rev. Microbiol. 2016, 14, 135-149. [CrossRef]

28. Jullesson, D.; David, F.; Pfleger, B.; Nielsen, J. Impact of synthetic biology and metabolic engineering on industrial production of fine chemicals. Biotechnol. Adv. 2015, 33, 1395-1402. [CrossRef]

29. Cardinale, S.; Arkin, A.P. Contextualizing context for synthetic biology-identifying causes of failure of synthetic biological systems. Biotechnol. J. 2012, 7, 856-866. [CrossRef]

30. Purnick, P.E.M.; Weiss, R. The second wave of synthetic biology: From modules to systems. Nat. Rev. Mol. Cell Biol. 2009, 10, 410-422. [CrossRef]

31. Pál, C.; Papp, B.; Pósfai, G. The dawn of evolutionary genome engineering. Nat. Rev. Genet. 2014, 15, 504-512. [CrossRef] [PubMed]

32. Reuß, D.R.; Altenbuchner, J.; Mäder, U.; Rath, H.; Ischebeck, T.; Sappa, P.K.; Thürmer, A.; Guérin, C.; Nicolas, P.; Steil, L.; et al. Large-scale reduction of the Bacillus subtilis genome: Consequences for the transcriptional network, resource allocation, and metabolism. Genome Res. 2016, 27, 289-299. [CrossRef] [PubMed]

33. Simon, U.; M, B.; Andreas, R.; Marius, H.; Daniel, S.; Natalie, B.; Anna, B.; Michael, B.; Wolfgang, W.; Kay, M.; et al. Chassis organism from Corynebacterium glutamicum-a top-down approach to identify and delete irrelevant gene clusters. Biotechnol. J. 2015, 10, 290-301.

34. Lieder, S.; Nikel, P.I.; Lorenzo, V.D.; Takors, R. Genome reduction boosts heterologous gene expression in Pseudomonas putida. Microb. Cell Fact. 2015, 14, 1-14. [CrossRef]

35. Juhas, M.; Reuß, D.R.; Zhu, B.; Commichau, F.M. Bacillus subtilis and Escherichia coli essential genes and minimal cell factories after one decade of genome engineering. Microbiol 2014, 160, 2341-2351. [CrossRef]

36. Zhu, B.; Stülke, J. SubtiWiki in 2018: From genes and proteins to functional network annotation of the model organism Bacillus subtilis. Nucleic Acids Res. 2018, 46, D743-D748. [CrossRef]

37. Gibson, D.G.; Glass, J.I.; Lartigue, C.; Noskov, V.N.; Chuang, R.; Algire, M.A.; Benders, G.A.; Montague, M.G.; Ma, L.; Moodie, M.M.; et al. Creation of a Bacterial Cell Controlled by a Chemically Synthesized Genome. Science 2010, 329, 52-57. [CrossRef]

38. Fredens, J.; Wang, K.; Torre, D.D.; Funke, L.F.H.; Robertson, W.E.; Christova, Y.; Chia, T.; Schmied, W.H.; Dunkelmann, D.L.; Beránek, V.; et al. Total synthesis of Escherichia coli with a recoded genome. Nature 2019, 569, 514-518. [CrossRef]

39. Juhas, M. On the road to synthetic life: The minimal cell and genome-scale engineering. Crit. Rev. Biotechnol. 2015, 36, 416-423. [CrossRef]

40. Chiang, S.M.; Schellhorn, H.E. Regulators of oxidative stress response genes in Escherichia coli and their functional conservation in bacteria. Arch. Biochem. Biophys. 2012, 525, 161-169. [CrossRef]

41. Weber, H.; Polen, T.; Heuveling, J.; Wendisch, V.F.; Hengge, R.; Ju, F.; Al, W.E.T. Genome-wide analysis of the general stress response network in Escherichia coli: sigmaS-dependent genes, promoters, and sigma factor selectivity. J. Bacteriol. 2005, 187, 1591-1603. [CrossRef] [PubMed]

42. Siguier, P.; File, J. Insertion sequences in prokaryotic genomes. Curr. Opin. Microbiol. 2006, 9, 526-531. [CrossRef] [PubMed]

43. Babakhani, S. Transposons: The agents of antibiotic resistance in bacteria. J. Basic Microbiol. 2018, 58, 905-917. [CrossRef] [PubMed]

44. Harms, H.; Bley, T.; Mu, S. Origin and analysis of microbial population heterogeneity in bioprocesses. Curr. Opin. Biotechnol. 2010, 21, 100-113.

45. Rugbjerg, P.; Myling-petersen, N.; Porse, A.; Sarup-lytzen, K.; Sommer, M.O.A. Diverse genetic error modes constrain large-scale bio-based production. Nat. Commun. 2018, 9, 787. [CrossRef]

46. Giovannoni, S.J.; Tripp, H.J.; Givan, S.; Podar, M.; Vergin, K.L.; Baptista, D.; Bibbs, L.; Eads, J.; Richardson, T.H.; Noordewier, M.; et al. Genome Streamlining in a Cosmopolitan Oceanic Bacterium. Science 2005, 309, 1242-1246. [CrossRef] 
47. Martínez-Cano, D.J.; Reyes-Prieto, M.; Martínez-Romero, E.; Partida-Martínez, L.P.; Latorre, A.; Moya, A.; Delaye, L. Evolution of small prokaryotic genomes. Front. Microbiol. 2015, 6, 1-23. [CrossRef]

48. Kafri, M.; Metzl-raz, E.; Jona, G.; Barkai, N. Article the Cost of Protein Production. Cell Reports 2016, 14, 22-31. [CrossRef]

49. Mizoguchi, H.; Mori, H.; Fujio, T. Escherichia coli minimum genome factory. Biotechnol. Appl. Biochem. 2007, 46, 157-167.

50. Shigenobu, S.; Watanabe, H.; Hattori, M.; Sakaki, Y.; Ishikawa, H. Genome sequence of the endocellular bacterial symbiont of aphids Buchnera sp. APS. Nature 2000, 407, 81-86. [CrossRef]

51. Hirokawa, Y.; Kawano, H.; Tanaka-Masuda, K.; Nakamura, N.; Nakagawa, A.; Ito, M.; Mori, H.; Oshima, T.; Ogasawara, N. Genetic manipulations restored the growth fitness of reduced-genome Escherichia coli. J. Biosci. Bioeng. 2013, 116, 52-58. [CrossRef] [PubMed]

52. Sambrook, J.; Russell, D.W. Molecular Cloning: A Laboratory Manual, 3rd ed.; Cold Spring Harbor Laboratory Press: New York, NY, USA, 1989; Volume 1, ISBN 9781936113415.

53. Mizoguchi, H.; Sawano, Y.; Kato, J.; Mori, H. Superpositioning of deletions promotes growth of Escherichia coli with a reduced genome. DNA Res. 2008, 15, 277-284. [CrossRef] [PubMed]

54. Kashiwagi, A.; Sakurai, T.; Tsuru, S.; Ying, B.; Mori, K.; Yomo, T. Construction of Escherichia coli gene expression level perturbation collection. Metab. Eng. 2009, 11, 56-63. [CrossRef] [PubMed]

55. Choe, D.; Lee, J.H.; Yoo, M.; Hwang, S.; Sung, B.H.; Cho, S.; Palsson, B.; Kim, S.C.; Cho, B. Adaptive laboratory evolution of a genome-reduced Escherichia coli. Nat. Commun. 2019, 10. [CrossRef] [PubMed]

56. Nishimura, I.; Kurokawa, M.; Liu, L.; Ying, B.W. Coordinated Changes in Mutation and Growth Rates Induced by Genome Reduction. MBio 2017, 8, 1-10. [CrossRef]

57. Yuan, X.; Couto, J.M.; Glidle, A.; Song, Y.; Sloan, W.; Yin, H. Single-Cell Microfluidics to Study the Effects of Genome Deletion on Bacterial Growth Behavior. ACS Synth. Biol. 2017, 6, 2219-2227. [CrossRef]

58. Kolisnychenko, V.; Iii, G.P.; Herring, C.D.; Fehér, T.; Pósfai, J.; Blattner, F.R.; Pósfai, G. Engineering a Reduced Escherichia coli Genome. Genome Res. 2002, 12, 640-647. [CrossRef]

59. Pósfai, G.; Umenhoffer, K.; Kolisnychenko, V.; Stahl, B.; Sharma, S.S. Emergent Properties of Reduced-Genome Escherichia coli. Science 2006, 312, 1044-1047. [CrossRef]

60. Karcagi, I.; Draskovits, G.; Umenhoffer, K.; Fekete, G.; Kovács, K.; Méhi, O.; Balikó, G.; Szappanos, B.; Györfy, Z.; Fehér, T.; et al. Indispensability of Horizontally Transferred Genes and Its Impact on Bacterial Genome Streamlining. Mol. Biol. Evol. 2016, 33, 1257-1269. [CrossRef]

61. Neidhardt, F.C.; Bloch, P.L.; Smith, D.F. Culture Medium for Enterobacteria. J. Bacteriol. 1974, 119, $736-747$.

62. Lee, J.H.; Sung, B.H.; Kim, M.S.; Blattner, F.R.; Yoon, B.H.; Kim, J.H.; Kim, S.C. Metabolic engineering of a reduced-genome strain of Escherichia coli for L-threonine production. Microb. Cell Fact. 2009, 8, 2. [CrossRef] [PubMed]

63. Ying, B.W.; Seno, S.; Kaneko, F.; Matsuda, H.; Yomo, T. Multilevel comparative analysis of the contributions of genome reduction and heat shock to the Escherichia coli transcriptome. BMC Genom. 2013, 14, 25. [CrossRef] [PubMed]

64. Ying, B.W.; Yama, K. Gene Expression Order Attributed to Genome Reduction and the Steady Cellular State in Escherichia coli. Front. Microbiol. 2018, 9, 1-9. [CrossRef] [PubMed]

65. Park, M.K.; Lee, S.H.; Yang, K.S. Enhancing recombinant protein production with an Escherichia coli host strain lacking insertion sequences. Appl. Microbiol. Biotechnol. 2014, 98, 6701-6713. [CrossRef]

66. Yu, B.J.; Sung, B.H.; Koob, M.D.; Lee, C.H.; Lee, J.H.; Lee, W.S.; Kim, M.S.; Kim, S.C. Minimization of the Escherichia coli genome using a Tn5-targeted Cre/loxP excision system. Nat. Biotechnol. 2002, 20, 1018-1023. [CrossRef]

67. Hall, B.G. Activation of the bgl Operon by Adaptive Mutation. Mol. Biol. Evol. 1988, 15, 1-5. [CrossRef]

68. Akeno, Y.; Ying, B.-W.; Tsuru, S.; Yomo, T. A reduced genome decreases the host carrying capacity for foreign DNA. Microb. Cell Fact. 2014, 13, 49. [CrossRef]

69. Couto, J.M.; Mcgarrity, A.; Russell, J.; Sloan, W.T. The effect of metabolic stress on genome stability of a synthetic biology chassis Escherichia coli K12 strain. Microb. Cell Fact. 2018, 1-10. [CrossRef]

70. Me, O.; Fekete, G. Competition between Transposable Elements and Mutator Genes in Bacteria. Mol. Biol. Evol. 2012, 29, 3153-3159.

71. Mushegian, A.R.; Koonin, E.V. A minimal gene set for cellular life derived by comparison of complete bacterial genomes. Proc. Natl. Acad. Sci. USA 1996, 93, 10268-10273. [CrossRef] 
72. Martínez-Carranza, E.; Barajas, H.; Alcaraz, L.D.; Servín-González, L.; Ponce-Soto, G.Y.; Soberón-Chávez, G. Variability of bacterial essential genes among closely related bacteria: The case of Escherichia coli. Front. Microbiol. 2018, 9, 1-7.

73. Baba, T.; Ara, T.; Hasegawa, M.; Takai, Y.; Okumura, Y.; Baba, M.; Datsenko, K.A.; Tomita, M.; Wanner, B.L.; Mori, H. Construction of Escherichia coli K-12 in-frame, single-gene knockout mutants: The Keio collection. Mol. Syst. Biol. 2006, 2, 1. [CrossRef] [PubMed]

74. Mori, H.; Baba, T.; Yokoyama, K.; Takeuchi, R.; Nomura, W.; Makishi, K.; Otsuka, Y.; Dose, H.; Wanner, B.L. Identification of essential genes and synthetic lethal gene combinations in Escherichia coli K-12. Methods Mol. Biol. 2015, 1279, 45-65. [PubMed]

75. Goodall, E.C.A.; Robinson, A.; Johnston, I.G.; Jabbari, S.; Turner, K.A.; Cunningham, A.F.; Lund, P.A.; Cole, J.A.; Henderson, I.R.; Kline, K.A. The Essential Genome of Escherichia coli K-12. MBio 2018, 9, e2096-17. [CrossRef]

76. Henry, C.S.; Overbeek, R.; Stevens, R.L. Building the blueprint of life. Biotechnol. J. 2010, 5, 695-704. [CrossRef]

77. Iwadate, Y.; Honda, H.; Sato, H.; Hashimoto, M.; Kato, J.I. Oxidative stress sensitivity of engineered Escherichia coli cells with a reduced genome. FEMS Microbiol. Lett. 2011, 322, 25-33. [CrossRef]

78. Wang, L.; Maranas, C.D. MinGenome: An in Silico Top-Down Approach for the Synthesis of Minimized Genomes. ACS Synth. Biol. 2018, 7, 462-473. [CrossRef]

79. Peebo, K.; Neubauer, P. Application of Continuous Culture Methods to Recombinant Protein Production in Microorganisms. Microorganisms 2018, 6, 56. [CrossRef]

80. Moran, N.A.; Mclaughlin, H.J.; Sorek, R. The Dynamics and Time Scale of Ongoing Genomic Erosion in Symbiotic Bacteria. Science 2009, 323, 379-382. [CrossRef]

81. Nutman, A.P.; Bennett, V.C.; Friend, C.R.L.; Van Kranendonk, M.J.; Chivas, A.R. Rapid emergence of life shown by discovery of 3,700-million-year-old microbial structures. Nature 2016, 537, 535-538. [CrossRef]

82. Good, B.H.; McDonald, M.J.; Barrick, J.E.; Lenski, R.E.; Desai, M.M. The dynamics of molecular evolution over 60,000 generations. Nature 2017, 551, 45-50. [CrossRef] [PubMed]

83. Jahn, L.J.; Munck, C.; Ellabaan, M.M.H.; Sommer, M.O.A. Adaptive Laboratory Evolution of Antibiotic Resistance Using Different Selection Regimes Lead to Similar Phenotypes and Genotypes. Front. Microbiol. 2017, 8, 1-14. [CrossRef] [PubMed]

84. Suzuki, S.; Horinouchi, T.; Furusawa, C. Prediction of antibiotic resistance by gene expression profiles. Nat. Commun. 2014, 5, 1-12. [CrossRef] [PubMed]

85. Horinouchi, T.; Suzuki, S.; Hirasawa, T.; Ono, N.; Yomo, T.; Shimizu, H.; Furusawa, C. Phenotypic convergence in bacterial adaptive evolution to ethanol stress. BMC Evol. Biol. 2015, 15, 180. [CrossRef] [PubMed]

86. Deatherage, D.E.; Kepner, J.L.; Bennett, A.F.; Lenski, R.E.; Barrick, J.E. Specificity of genome evolution in experimental populations of Escherichia coli evolved at different temperatures. Proc. Natl. Acad. Sci. USA 2017, 114, E1904-E1912. [CrossRef]

87. Kishimoto, T.; Iijima, L.; Tatsumi, M.; Ono, N.; Oyake, A.; Hashimoto, T.; Matsuo, M.; Okubo, M.; Suzuki, S.; Mori, K.; et al. Transition from positive to neutral in mutation fixation along with continuing rising fitness in thermal adaptive evolution. PLoS Genet. 2010, 6, e1001164. [CrossRef]

88. Tenaillon, O.; Rodríguez-Verdugo, A.; Gaut, R.L.; McDonald, P.; Bennett, A.F.; Long, A.D.; Gaut, B.S. The molecular diversity of adaptive convergence. Science 2012, 335, 457-461. [CrossRef]

89. Hamdallah, I.; Torok, N.; Bischof, K.M.; Majdalani, N.; Chadalavada, S.; Mdluli, N. crossm Experimental Evolution of Escherichia coli K-12 at High pH and with RpoS Induction. Appl. Environ. Microbiol. 2018, 84, 1-17. [CrossRef]

90. Palsson, B.O.; Feist, M. Use of Adaptive Laboratory Evolution To Discover Key Mutations Enabling Rapid Growth of Escherichia coli K-12 MG1655 on Glucose Minimal Medium. Appl. Environ. Microbiol. 2015, 81, $17-30$.

91. Conrad, T.M.; Lewis, N.E.; Palsson, B.O. Microbial laboratory evolution in the era of genome-scale science. Mol. Syst. Biol. 2014, 7, 509. [CrossRef]

92. Toprak, E.; Veres, A.; Michel, J.; Chait, R.; Hartl, D.L.; Kishony, R. Evolutionary paths to antibiotic resistance under dynamically sustained drug selection. Nat. Genet. 2011, 44, 101-105. [CrossRef] [PubMed] 
93. McCloskey, D.; Xu, S.; Sandberg, T.E.; Brunk, E.; Hefner, Y.; Szubin, R.; Feist, A.M.; Palsson, B.O. Evolution of gene knockout strains of E. coli reveal regulatory architectures governed by metabolism. Nat. Commun. 2018, 9, 3796. [CrossRef] [PubMed]

94. Ho, W.; Zhang, J. Evolutionary adaptations to new environments generally reverse plastic phenotypic changes. Nat. Commun. 2018, 1-11. [CrossRef] [PubMed]

(C) 2019 by the authors. Licensee MDPI, Basel, Switzerland. This article is an open access article distributed under the terms and conditions of the Creative Commons Attribution (CC BY) license (http://creativecommons.org/licenses/by/4.0/). 